\title{
Employers' Needs and Expectations for Qualified Employees (Case Study on the Opinions in One of the Regions in Latvia)
}

\author{
Biruta Sloka $^{1}$, Ināra Kantāne ${ }^{2}$, Ilze Buligina ${ }^{3}$, Ginta Tora ${ }^{4}$, Juris Dzelme ${ }^{5}$, Regīna Buševica ${ }^{6}$, \\ Alise Buligina ${ }^{7}$, Pēteris Tora ${ }^{8},{ }^{1-7}$ University of Latvia,${ }^{8}$ Erasmus University Rotterdam
}

\begin{abstract}
Qualified, loyal and motivated employees are highly demanded by employers and business promoters. The paper deals with employers' needs and expectations for qualified and loyal employees, and investigates cooperation of employers, educators and municipalities. The following methods were used: analysis of scientific publications; focus group discussions; surveys of employers, teaching staff, students and graduates of VEI. For survey data analysis descriptive statistical analysis, non-parametric statistical test of Kruskal-Wallis and factor analysis were applied. The main findings indicate that besides professional skills and competence, social competence, motivation to work and responsibility are requested as well.
\end{abstract}

Keywords - Education, motivation, practice, qualified workforce.

\section{INTRODUCTION}

The academic research worldwide has paid a lot of attention to employers' needs and expectations for qualified workforce, since such research results are relevant for various groups of stakeholders: representatives of public administrations to make informed policy development decisions, education institutions to develop adequate education and training programs in compliance with the labour market needs, as well as the potential students and their relatives to be guided for the best possible solution in making their choice of an education institution and education pathway. New developments in IT solutions and web possibilities motivate researchers to focus their research in new directions regarding credibility of the individual's competencies in relation to the employers' needs.

In the National Development Plan of Latvia for 2014 2020 the necessity to increase economic activity in the regions by encouraging the development of business activity and the developing and utilising the potential of educational institutions has been underlined. The need to increase the state participation in the development of economics has been stressed in recent academic investigations (Chang, 2011). Public administration must be informed about the employer's needs and must organize the work of the education system accordingly. The state government together with local municipalities must help employees to receive the necessary qualifications according to the strategic development plans of national economies. This task is difficult in free market situations and specific research on it becomes important especially during economic crisis. Public administration must use the results of academic research to revise the education plans with the labour market to prevent and avoid the effects of economic crisis.

Qualified workforce is the main resource for industry. Quickly changing needs of employers for qualified employees create big difficulties for the education system to prepare the necessary specialists in time. Direct cooperation of employers and educators becomes an important tool to improve the fitness of education. New forms of vocational education and practice arise (Paisery \& Paisery, 2010; Ellström \& Ellström, 2014), but not all problems are solved and new problems appear (Plump, 2010). Participation of public administration in the organization of education and training becomes more important than before and helps to introduce new, more effective forms of vocational education and practice. There are not enough investigations on different possibilities of cooperation of employers, educators and public administrations.

The aim of the current research is to investigate the employers' needs and expectations for qualified employees and their readiness to participate in the creation of competitive labour force in Kurzeme region in Latvia.

The following research methods were applied: analysis of scientific publications and focus group discussions of municipality officials and educators; surveys of employers, teaching staff and students and graduates of vocational education institutions.

\section{THEORETICAL BACKGROUND}

One of the most important success factors of each business is competitive and qualified labour force and the ways and means of obtaining it are researched worldwide in all continents from different aspects and angles. Researchers of the United States have found that rapidly expanding attempts to use company websites to e-recruit job applicants have in many cases resulted in poorly qualified individuals (Mauer \& Cook, 2011). The research results in France have proved that there are different views on the role of employer's beliefs in the evaluation of education output (Bailly, 2008). New forms of vocational education have a significant coverage on education issues, like work-based learning, developing skills via work placements in different fields (Paisery \& Paisery, 2010). Several evaluations of learning outcomes of a workbased training and the significance of managerial support have been covered in the research of Swedish researchers Eva Ellström and Per - Erik Ellström who have reasonable and 
proved findings on the importance of management support for effective realisation of work-based training programme (Ellström \& Ellström, 2014). The work-based training has different influencing aspects regarding country and training level (Orr, \& Simmons, 2011), as well as participation rates (Thomas \& Qiu, 2012), different research methods applied to find better solutions, like insider researcher (Workman, 2007), enhancing innovation and creativity in teaching (Workman, et al., 2011). Employers often face also such employee problems as productivity, issues of morale, poor performance and other problems (Plump, 2010). Several Canadian scientists have devoted their research to qualitative investigation of employee business awareness and perception of knowledge (Haines III, et al., 2012). Employer benefits from making workplace accommodations are widely researched by the scientists of the United States of America who have found that the most frequently mentioned direct benefits were retained employees, increased worker productivity and eliminated cost of training of new employees (Solovieva, et al., 2011). Different countries (Bieneck \& Wettberg, 2006; Koreamäki \& Kyyrä, 2005; Hass, et al., 2011) have different approaches taking into account gender pay gap (Hirsch, 2013) and different wage subsidy participation (Welters \& Muysken, 2007). Slovak researchers have found the factors for determining company efficiency through the investment to the employees as well as have investigated quantitative valuation (Korenkova \& Urbanikova, 2014). Several studies on the selection process history were studied as well (Schulz, et al., 2014) and Hynninen, et al., 2013) for better findings of current effective labour market solutions (Nikandrou, et al., 2009) as well as a variety of other fields (Tidwell, et al., 2009). Maxwell, et al., (2010) have stated that key points for employers as stakeholders in postgraduate employability skills development are that employers themselves can increase their stake in employability skills development in two ways: by working in partnership with universities on the core and component skills they seek from graduates and by assuming their share of responsibility for the development of these skills. Recommendations on the role of postsecondary education in workforce development and challenges have been developed for state policy paying special attention to expectations of employers, learners, government and general public to be set as a starting point for discussions between the state, education and business leaders in order to develop strategies satisfactory for all parties involved in the issues (Wallhaus, 1996). The research results of Wallhaus (1009) confirmed that employers are placing an increasing demand for basic education skills, such as in mathematics and communication, and basic workplace skills, such as teamworking, interpersonal relations, and leadership. In many studies carried out world-wide detailed analysis for skills needs for respective professions are carried out, like for accountants (Kavenagh and Derunan, 2008) where expectations of students and employers on competitive professionals are analysed and as result has been stated that employers besides expectations of good understanding of basic accounting skills and strong analytical skills are also requiring business awareness and knowledge in terms of the "real world". Attention to equal opportunities is under research angle as well - considering requirements of employers under the labour code (Kleiner, 2005). Vocational education and training attrition and the school-to-work transition is on the research agenda also of the researchers from Canada and Switzerland (Masdonati and Jordan, 2010) where aspects related to difficulties with the shift from a standard school system in VET as well as difficulties in learning, relational of working environment has been examined. Integration of entrepreneurship education in the vocational training system has particular focus in many countries and different aspects of better realisation of this approach (Nkirina, 2010). Researchers from Finland Mika Maliranta, Satu Nurmi and Hanna Virtanen have concluded that teachers with university degree increase the employment probability of the students, whereas formal competence of the teachers does not have such positive effects. The students' characteristics and performance in comprehensive schools play an important role in determining the outcomes. Local business conditions affect the outcomes of boys, but less those of girls (Maliranta, et al., 2010).

Vincent Carpentier with his colleagues from the UK have explored the efforts to bridge conceptualisation and practice in work-based learning by reflecting on the legacy and sustainability and have focused on exploring the ways of transforming current methods of work-based learning in a bid to respond to the diversity of professional learning needs within education and beyond and have confirmed successfully moving knowledge from disciplines and workplaces into a curriculum and from a curriculum into successful pedagogic strategies and learner engagement in educational institutions and workplaces (Carpentier, et al., 2011). Vincent Carpentier with his colleagues has light up innovative ways to continue to develop understanding of work-based learning and informed practice: the impact of work-based learning activities on theory, policy and practice has been found evident in the creation of national and international platforms strengthening existing institutional links and makes inspirations for other researchers, practitioners and policy makers.

Various international institutions have developed a considerable amount of policy documents (European Centre for the Development of Vocational Training, 2013). Corporate recruiters' survey conducted by the Graduate Management Admission Council annually from 2001 and carried out in 40 countries worldwide reflected the needs of employers in respect to expectations for graduates (Estrada, 2012). Other aspects of competitive workforce selection and preparation are on the research agenda for scientists in many countries around the globe, and the results are expected and being used by policy makers, by public administrators, by educators on different education levels as well as by employers.

\section{RESEARCH RESULTS}

The survey of employers in Kurzeme region of Latvia was conducted from June to December 2013. The company register LURSOFT was used for the selection of respondents. 
All large and medium companies of Kurzeme region were included in the sample. To ensure a random selection of small companies, the mechanical selection of units was applied (every fifth company was included in the sample). The web survey and the phone survey were used. At first the respondents were called on the phone and invited to participate in the survey and fill out the questionnaire located on the professional research company server. For some respondents who had difficulties to fill in the web survey form, the survey was implemented through a telephone interview and the questionnaire was filled out by the interviewer. If the questionnaire was not filled by the approached company in one week, the respondents were called by phone once more and asked to do it. The third call to the entrepreneurs who had not yet filled out the questionnaire was made in two weeks. In Kurzeme region 1549 employers were approached and 336 responses received (the response rate was $19.5 \%$ ).

Several issues were examined in the survey; however, this paper evaluates in more detail specifically the employers' needs and expectations for qualified employees and their readiness to participate in the creation of competitive labour force in Kurzeme region in Latvia. For the evaluations of the respondents' attitude towards the research aspects in the questionnaire the scale 1-10 was used.

For survey data analysis descriptive statistical analysis (indicators of central tendency or location, indicators of variability), non-parametric statistical test of Kruskal-Wallis, as well as the method of multivariate statistical analysis factor analysis have been applied.

Approximately $38 \%$ of employers pointed out that their company was in need or in next three years would require new employees. The employers highly evaluated the following skills and attitudes when hiring new employees: ability for self-contained work, ability to plan work time, computer literacy, co-operation ability, initiative and creativity, intelligence, involvement, knowledge, skills, solidity and allegiance to company, specific professional knowledge, willingness in skills improvement. However, it should be noted that the evaluations were highly heterogeneous and surprisingly high evaluated. The employers evaluated the solidity and allegiance to the company of new employees with the highest arithmetic mean 8.2, median 8.5 (median - having the implication that half of the employers gave evaluations lower than 8.5 and half of employers gave evaluations higher than 8.5) and mode 10 (mode - most often met evaluation of the statement by employers). High evaluations were given also for the ability to plan work time (arithmetic mean 7.9, median 8 , mode 10), ability for self-contained work (arithmetic mean 7.9 , median 8 , mode 10), co-operation ability (arithmetic mean 7.9 , median 8 , mode 10 ), high evaluations of employers were given also for involvement and for intelligence. The average indicators of employers' evaluation of employee's skills and attitudes obtained are presented in Fig. 1.

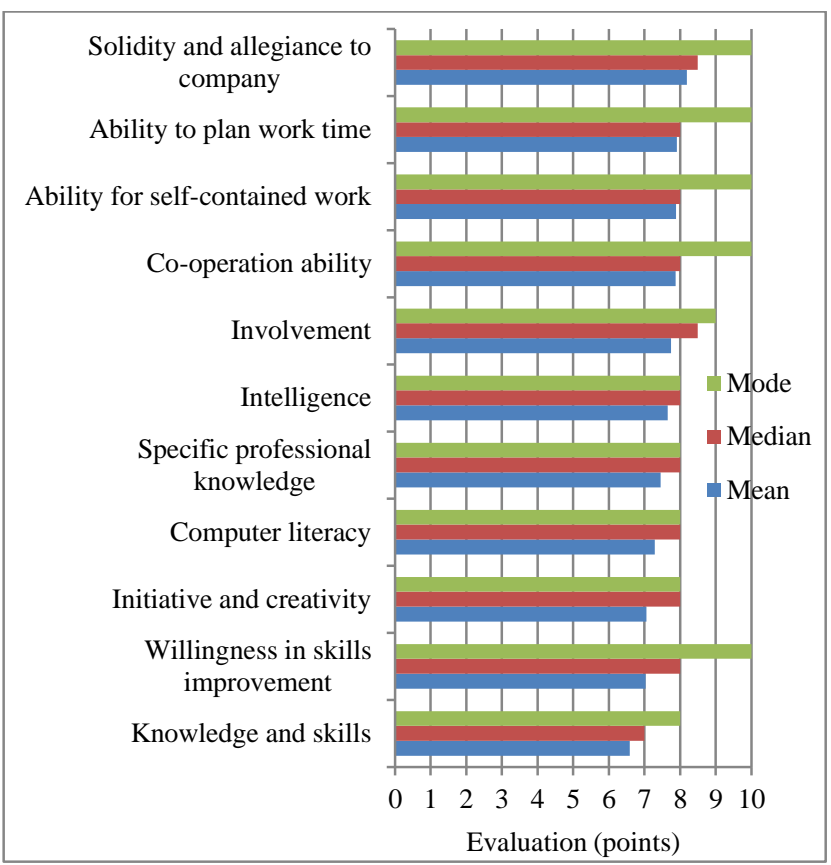

Fig. 1. Average (mean, median and mode) indicators of employers' evaluation of employees' skills and attitudes. Those are important when hiring new employees. Source: compiled by authors based on the employers' survey, 2013 ( $n=336)$. Evaluation scale $1-10$, where 1 - unimportant; 10 - extremely important.

For identifying the key factors - employee's skills and attitudes which are important when hiring new employees and for determining the mutual statistical relations of the factors, the factor analysis was used. Eleven initial factors were chosen. As a result of the factor analysis, the initial 11 factors, through three rotation iterations (by using the Varimax rotation), were grouped in 2 complex factors (see Table I).

TABLE I

ANALYSIS OF IMPORTANT FACTORS WHEN HIRING NEW EMPLOYEES (COMPLEX FACTOR MATRIX AFTER ROTATION)

\begin{tabular}{|l|c|c|}
\hline \multirow{2}{*}{} & \multicolumn{2}{|c|}{ Factors } \\
\cline { 2 - 3 } & F1 & F2 \\
\hline Ability for self-contained work & 0.881 & 0.215 \\
\hline Ability to plan work time & 0.880 & 0.226 \\
\hline Involvement & 0.859 & 0.301 \\
\hline Co-operation ability & 0.849 & 0.220 \\
\hline Intelligence & 0.815 & 0.459 \\
\hline Solidity and allegiance to company & 0.775 & 0.300 \\
\hline Initiative and creativity & 0.754 & 0.550 \\
\hline Willingness in skills improvement & 0.709 & 0.418 \\
\hline Computer literacy & 0.151 & 0.886 \\
\hline Knowledge skills & 0.319 & 0.845 \\
\hline Specific professional knowledge & 0.569 & 0.689 \\
\hline $\begin{array}{l}\text { Extraction Method: Principal Component Analysis. } \\
\text { Rotation Method: Varimax with Kaiser Normalization. }\end{array}$ \\
\hline a. Rotation converged in 3 iterations. \\
\hline
\end{tabular}

Source: compiled by authors based on employers' survey, $2013(n=336)$. Evaluation scale 1-10, where 1 - unimportant; 10 - extremely important. 
Further the interpretation of the identified complex factors as a result of the factor analysis (with regard to the indicators with which the initial indicators have relatively high burdens) is presented:

1) Complex factor F1 - social competence; the factor has relatively high burden on the following employee's skills and attitudes: ability for self-contained work, ability to plan work time, involvement, co-operation ability, intelligence, solidity and allegiance to company, initiative and creativity, willingness in skills improvement.

2) Complex factor F2 - specific skills; the factor has relatively high burden on the following employee's skills and attitudes needed: computer literacy, knowledge skills, specific to the respective speciality required professional knowledge.

Employers in Kurzeme region of Latvia in general agreed that innovative approaches in the VET system in Latvia should be introduced in order to train a competitive labour force arithmetic mean 7.9 , mode 10 , median 8 , and in principle supported the introduction of work-based learning the VET system in Latvia - arithmetic mean 6.1, mode 5, median 6. However, it should be noted that the evaluations were not homogenous. The main statistical indicators are reflected in Table II.

TABLE II

MAIN STATISTICAL INDICATORS OF EMPLOYERS' EVALUATION OF STATEMENTS "DO YOU AGREE THAT INNOVATIVE APPROACHES IN THE VET SYSTEM IN LATVIA SHOULD BE INTRODUCED IN ORDER TO TRAIN A COMPETITIVE LABOUR FORCE?" AND "DO YOU IN PRINCIPLE SUPPORT INTRODUCTION OF WORK-BASED LEARNING IN VET SYSTEM IN LATVIA?"

\begin{tabular}{|l|c|c|c|c|c|c|}
\hline & Mean & Median & Mode & $\begin{array}{l}\text { Standard } \\
\text { Deviation }\end{array}$ & Maximum & Minimum \\
\hline $\begin{array}{l}\text { Do you agree that } \\
\text { innovative } \\
\text { approaches in the } \\
\text { VET system in } \\
\begin{array}{l}\text { Latvia should be } \\
\text { introduced in order to } \\
\text { train a competitive } \\
\text { labour force? }\end{array}\end{array}$ & 7.9 & 8 & 10 & 1.9 & 10 & 1 \\
\hline $\begin{array}{l}\text { Do you in principle } \\
\text { support the } \\
\text { introduction of work- } \\
\text { based learning in } \\
\text { VET system in } \\
\text { Latvia? }\end{array}$ & 6.1 & 6 & 5 & 2.9 & 10 & 1 \\
\hline
\end{tabular}

Source: compiled by authors based on employers' survey, $2013 \quad(n=336)$ Evaluation scale 1-10, where 1 - don't agree/don't support; 10 - agree/ support.

In general employers were very positive and interested to get competitive employees and were very positive towards their own participation in the pilot project of the dual workbased training realised together with vocational education establishments. Approximately $16.3 \%$ of the surveyed employers indicated that they would certainly be willing to participate in the pilot project of the dual or work-based training to be implemented in cooperation with vocational schools, approximately $22.9 \%$ would be generally willing, but $11.4 \%$ were not ready to participate, more than half of the employers in a ten point evaluation scale gave evaluations 5 or more (see Fig. 2).

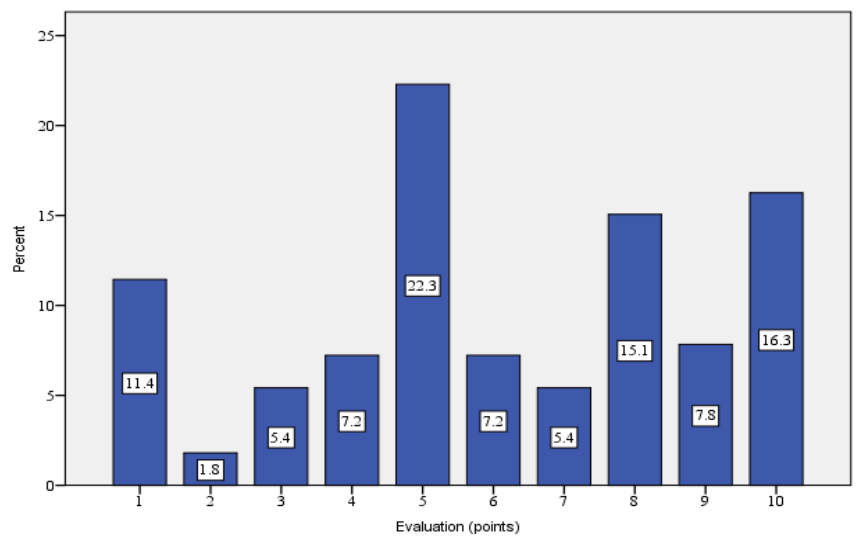

Fig. 2. Employers' evaluation of the statement: "To what extent would your company be willing to participate in the pilot project of the dual world of work-based training implemented in cooperation with vocational schools?" Source: compiled by authors based on employers' survey, $2013(n=336)$. Evaluation scale 1-10, where 1 - not be ready; 10 - certainly be ready.

The employers with secondary education level evaluated the possibility to participate in the pilot project of the dual or work-based training implemented in cooperation with vocational schools, lower than the employers with higher education (arithmetic mean 4, median 4, mode 1). However, it should be noted that the evaluations were quite heterogeneous. The evaluations of employers with bachelor's degree and master's degree were the highest and the evaluations were quite homogenous (see Table III).

TABLE III

MAIN STATISTICAL INDICATORS OF STATEMENT “TO WHAT EXTENT WOULD YOUR COMPANY BE WILlING TO PARTICIPATE IN THE PILOT PROJECT OF THE DUAL WORLD OF WORK-BASED TRAINING IMPLEMENTED IN COOPERATION WITH VOCATIONAL SCHOOLS" DEPENDING ON THE LEVEL OF EDUCATION OF EMPLOYERS

\begin{tabular}{|c|c|c|c|c|c|c|}
\hline $\begin{array}{c}\text { Education } \\
\text { level }\end{array}$ & Mean & Median & Mode & $\begin{array}{l}\text { Standard } \\
\text { Deviation }\end{array}$ & $\begin{array}{l}\text { Mini- } \\
\text { mum }\end{array}$ & $\begin{array}{l}\text { Maxi- } \\
\text { mum }\end{array}$ \\
\hline $\begin{array}{l}\text { Secondary } \\
\text { education }\end{array}$ & 4 & 4 & 1 & 3.3 & 1 & 7 \\
\hline $\begin{array}{l}\text { First level } \\
\text { higher } \\
\text { professional } \\
\text { education } \\
\text { (college) }\end{array}$ & 6 & 6 & 4 & 3.1 & 1 & 10 \\
\hline $\begin{array}{l}\text { Professional } \\
\text { higher } \\
\text { education }\end{array}$ & 7 & 6 & 8 & 2.2 & 4 & 10 \\
\hline $\begin{array}{l}\text { Professional } \\
\text { secondary } \\
\text { education }\end{array}$ & 6 & 6 & 10 & 3.5 & 1 & 10 \\
\hline $\begin{array}{l}\text { Bachelor } \\
\text { degree }\end{array}$ & 7 & 8 & 9 & 1.8 & 5 & 9 \\
\hline $\begin{array}{l}\text { Professional } \\
\text { bachelor } \\
\text { degree }\end{array}$ & 5 & 5 & 5 & 0.0 & 5 & 5 \\
\hline $\begin{array}{l}\text { Master } \\
\text { degree }\end{array}$ & 7 & 7 & 5 & 1.4 & 5 & 8 \\
\hline $\begin{array}{l}\text { Professional } \\
\text { master } \\
\text { degree }\end{array}$ & 6 & 7 & 1 & 3.5 & 1 & 10 \\
\hline
\end{tabular}

Source: compiled by authors based on employers' survey, $2013 \quad(n=336)$. Evaluation scale 1-10, where 1 - not ready; 10 - certainly ready 
It must be noted that the employers' average evaluation did not differ statistically significantly by the education level of employers (Kruskal-Wallis test $\chi 2=-8.283, p=0.218$ ).

As one of the main reasons why a company did not offer practical placements the employers mentioned lack of financing in the company (arithmetic mean 6.9, median 9, mode 10). The employers gave a high evaluation also for: not appropriate working places to offer for practical placements. It should be noted that the evaluations were quite heterogeneous. The main statistical indicators are reflected in Table IV.

\section{TABLE IV}

MAIN STATISTICAL INDICATORS ON STATEMENT "Does your Company OfFER Practical Placement Places"

\begin{tabular}{|l|c|c|c|c|c|c|}
\hline & $\begin{array}{c}\text { No } \\
\text { financing }\end{array}$ & $\begin{array}{c}\text { Not } \\
\text { appropria- } \\
\text { te } \\
\text { working } \\
\text { places }\end{array}$ & $\begin{array}{c}\text { Specifics } \\
\text { of } \\
\text { company } \\
\text { do not } \\
\text { allow }\end{array}$ & $\begin{array}{c}\text { Nobody } \\
\text { applied }\end{array}$ & $\begin{array}{c}\text { Disturbs } \\
\text { everyday } \\
\text { work }\end{array}$ & $\begin{array}{c}\text { Not } \\
\text { assumed }\end{array}$ \\
\hline Mean & 6.9 & 6.1 & 5.9 & 4.7 & 5.4 & 6.5 \\
\hline $\begin{array}{l}\text { Std. Error of } \\
\text { Mean }\end{array}$ & 0.5 & 0.4 & 0.4 & 0.5 & 0.3 & 0.4 \\
\hline Median & 9 & 5 & 5 & 4.5 & 6 & 7 \\
\hline Mode & 10 & 5 & 5 & 1 & 1 & 10 \\
\hline Std. Deviation & 3.7 & 3.3 & 3.0 & 3.6 & 3.4 & 3.8 \\
\hline Range & 9 & 9 & 9 & 9 & 9 & 9 \\
\hline Minimum & 1 & 1 & 1 & 1 & 1 & 1 \\
\hline Maximum & 10 & 10 & 10 & 10 & 10 & 10 \\
\hline
\end{tabular}

Source: compiled by authors based on employers' survey, $2013(n=336)$. Evaluation scale $1-10$, where 1 - don't agree; don't support; 10 - agree; support

In focus group discussions employers mentioned that in general they were willing to cooperate with their municipality. The employers highly evaluated municipality support and tax benefits, as motivating factors for the involvement of vocational education students by the company. The average indicators of employers' evaluation of motivation by their municipality for the involvement of vocational education students by the company are presented in Fig. 3.

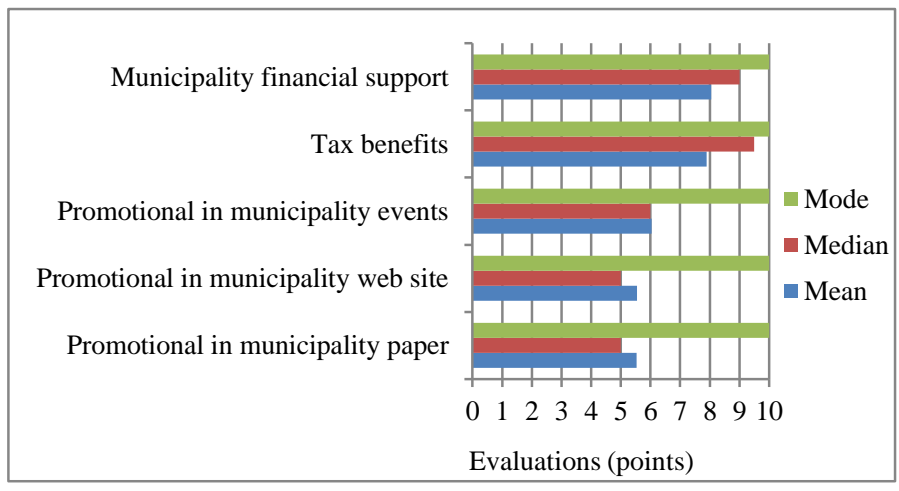

Fig. 3. Average (mean, median and mode) indicators of employers' evaluation of municipality motivation activities for involvement of vocational education students by company. Source: compiled by authors based on employers' survey, $2013(n=336)$. Evaluation scale $1-10$, where 1 - not significant; 10 very significant.
The main findings of the current research indicate that apart from professional skills and competence, also social competence, motivation to work and responsibility are highly evaluated and requested by the employers. Solidity and allegiance to company is most required for new employees (see Fig. 2).

Students of vocational education institutions besides good salary expect also the stability of employment. A rather high share of students expects also good career development. The results of the empirical studies when compared with the theoretical findings of researchers in other countries have shown that by large the empirical results correspond with the theoretical conclusions suggested by scientists in many other countries.

The research was carried out for Kurzeme region of Latvia, but the main results are valid for the whole of Latvia and similar countries, mainly in Central and Eastern Europe. Culture and ethics create important conditions for business therefore relations of employers with employees are different in Western countries and outside Europe. The received results will be of limited use outside the Central and East European region. Additional research is necessary for the recommendations concerning countries other than Latvia, but the authors believe that the general trends will be the same. Cooperation between education system, employers and public administration seems to be important in a wide range of political, economic and cultural conditions and should be investigated and planned for ensuring sustainable development. Mechanisms of free market are not enough to cope with long term problems, such as receiving and maintaining qualifications of employees necessary for the successful functioning of the economic system.

The current research deals mainly with the problems of VET system. The existing small and medium size enterprises need first of all specialists from VET system, but future development will create bigger need for specialists with higher education. The main conclusions about the cooperation should be valid for VET and higher education, but additional investigation will be necessary.

\section{CONCLUSION}

Labour market often cannot supply the necessary new employees according to the fast changing needs of employers. There are at least two ways to solve employers' problems to find qualified, motivated and loyal employees by using the education system.

One possibility is to organise practice for the potential employees and to establish contacts with the appropriate candidates during the practical placement. This may have different problems, listed in Table IV, first of them being the lack of financing. The easiest task is to find applicants for the practical placement (see Table IV). The support of state and local municipalities could improve the current situation. Fig. 3, as well as Table IV show that financial support, including tax benefits, is the most important kind of support.

Another possibility is to help the loyal employees already engaged in the enterprise by motivating highly enough to 
acquire the necessary qualification. The employers support innovative approaches in the VET system including workbased learning, but individual opinions are very different (see Fig. 2, Table II, Table III). Big difference in employers' opinion could arise from the problems with appropriate information about the recent developments in VET system. It seems that the data in Table III could confirm this, because lower skills to receive information in the case of secondary level education of employers leads to lower support for the dual education.

In both cases good cooperation between the education institutions and enterprises is necessary. For small and medium size enterprises the support from state and local municipalities is essential. The use of the dual education model (or work-based learning) could be highly effective. The necessary improvements of the state regulations for education are important to help the employers and employees to improve cooperation for the mutual benefit from work results.

According to the received results the variability of opinions of employers is rather big. It is very difficult to create joint strategy based on individual decisions of the employers. The two ways to improve cooperation of the employers in the framework of the projects for the development of the professional education of employees are: 1) involvement of existing associations of employers or creation of new organizations, targeted to cooperation with educational institutions, local communities and state; 2) use of created by state forms of cooperation between educational institutions, enterprises and state, such as NEP ("Branch Expert Councils"). Most of the enterprises in Latvia are small or medium size, therefore such special means for the improvement of cooperation and involvement of local communities are essential.

The discussions about the employers' needs could be divided in two main parts - social competence (complex factor F1, see Table I) and specific skills (complex factor F2, see Table I). Social competence of employees could be discussed with state and national organizations, including the authorities responsible for general education. Organizations, such as NEP, responsible for the strategic plans and their implementation in different branches of economics are appropriate for the discussion about the development of specific skills. Our results indicate, that such division of problems under discussion concerning employers' needs (see Table I) could be useful.

\section{ACKNOWLEDGMENT}

Authors express thanks for the assistance and support in survey data collection to Ilona Ozolina, Irina Bausova, Svetlana Saksonova, Vineta Dadeka, Aiga Petkeviča.

\section{REFERENCES}

Bailly, F. (2008). The Role of Employers Beliefs in the Evaluation of Education output. The Journal The Journal of Socio - Economics, 37, 959-968. http://dx.doi.org/10.1016/j.socec.2006.12.083

Bieneck, H.-J., Wettberg, W. (2006). The German Employer Model. International Congress Series, 1294, 49-52. http://dx.doi.org/10.1016/j.ics.2006.01.060
Carpentier, V., Pachler, N., Evans, K., Daly, C. (2010). Work-Learn-Educate: the WLE Centre for Excellence's Conceptualisation of Work-Based Learning, Skills and Work-Based Learning, 1(3), 216-230. http://dx.doi.org/10.1108/20423891111179623

Chang, H.J. (2011). Institutions and Economic Development: Theory, Policy, and History. Journal of Institutional Economics, 7:4, 473-498. http://dx.doi.org/10.1017/S1744137410000378

Ellström, E., Ellström, P.E. (2014). Learning Outcomes of a Work - Based Training Programme. European Journal of Training and Development, 28(1), 180-197. http://dx.doi.org/10.1108/EJTD-092013-0103

Estrada, R. (2012). 2012 Corporate Recruiters Survey Report, Graduate Management Admission Council, 1-36.

European Centre for the Development of Vocational Training (2013) Identifying skills needs. Retrieved September 6, 2014 from http://www.cedefop.europa.eu/EN/identifying-skillsneeds/index.aspx

Haines III, V.Y., Rosseau, V., Brotheridge, C.M, Saint_Onge, E. (2012). A Qualitative Investigation of Employee Business Awareness. Personnel Review, 11(1), 73-87.

Hassi, A., Storti, G., Azennoud, A. (2011). Corporate Trainers'Credibility and Cultural Values: Evidence from Canada and Morrocco. Cross Cultural Management, $18(4), \quad 499-519$. http://dx.doi.org/10.1108/13527601111179546

Hirsch, B. (2013). The Impact of Female Managers on the Gender Pay Gap: Evidence from Linked Employer - Employee Data for Germany. Economics Letters, 119, 348-350. http://dx.doi.org/10.1016/j.econlet.2013.03.021

Hynninen, S.-M., Ojala, J., Pehkonen, J. (2013). Technological change and Wage Premiums: Historical Evidence from Linked Employer Employee Data. Labour Economics, 2013, 1-11. http://dx.doi.org/10.1016/j.labeco.2013.05.006

Kavanagh, Marie H.; Drennan, Lyndal. (2008). What Skills and Attributes does an Accounting Graduate Need? Evidence from Student Perceptions and Employer Expectations. Accounting \& Finance. 48(2), 279-300. http://dx.doi.org/10.1111/j.1467-629X.2007.00245.x

Korenkova, M., Urbanikova, M. (2014). Increase of Company Efficiency through the Investment to the Employees and its Quantitative Valuation. Procedia - Social and Behavioral Sciences, 110, 942951. http://dx.doi.org/10.1016/j.sbspro.2013.12.940

Korkeamäki, O., Kyyrä, T. (2006). A Gender Wage Gap Decomposition for Matched Employer - Employee Data. Labour Economics. 13, 611638. http://dx.doi.org/10.1016/j.labeco.2005.02.001

Maliranta, M., Nurmi, S., Virtanen, H. (2010). Resources in Vocational Education and Poast - Schooling Outcomes. International Journal of Manpower, 32(5), http://dx.doi.org/10.1108/01437721011066344

$520-544$.

Masdonati, J., Lammamra, N., Jordan, M. (2010). Vocational Education and Training Attrition and the School - to Work Transition. Education + Training, $52(5)$, 404-414. http://dx.doi.org/10.1108/00400911011058343

Maurer, S.D. \& Cook, D.P. (2011). Using Company Web Sites to E - Recruit Qualified Applicants: A Job Marketing Based Review of Theory Based Research. Computers in Human Behaviour, 27, 106-117. http://dx.doi.org/10.1016/j.chb.2010.07.013

Maxwell, G., Scott, B., Macfarlane, D., Williamson, E. (2009). Employers as Stakeholders in Postgraduate Employability Skills Development. International Journal of Management Education, 8(2), 1-12, http://dx.doi.org/10.3794/ijme.82.267

National Development Plan of Latvia for 2014-2020. Available: http://www.pkc.gov.lv/images/NAP2020\%20dokumenti/NDP2020_E nglish_Final.pdf. (15.10.2014).

Nikandrou, I., Brinia, V., Bereri, E. (2009). Trainee Perceptions of Training Transfer: an Empirical Analysis. Journal of European Industrial Training, 33(4), 255-270. http://dx.doi.org/10.1108/03090590910950604

Nkirina, S.P. (2010). The Challenges of Integrating Entrepreneurship Education in the Vocational Training System. Journal of European Industrial Training, 34(2), 153-166. http://dx.doi.org/10.1108/03090591011023998

Orr, K., Simmons, R. (2011). The Work - Based Learning Experience of Trainee Teachers in English Further Education Colleges. Journal of $\begin{array}{lll}\text { Workplace Learning, 23(4), 243-257. } & \end{array}$ http://dx.doi.org/10.1108/13665621111128664 
Paisey, C. \& Paysey, N.J. (2010). Developing Skills via Work Placements in Accounting: Student and Employer Views. Accounting Forum, 34 89-108. http://dx.doi.org/10.1016/j.accfor.2009.06.001

Plump, C.M. (2010). Dealing with Problem Employees: a Legal Guide for Employers. Business Horizons, 53, 607-618. http://dx.doi.org/10.1016/j.bushor.2010.07.003

Schulz, W., Maas, I., van Leeuwe, M.H.D. (2014). Employer's Choice Selection through Job Advertisements in the Nineteenth and Twentieth Centuries. Research in Social Stratification and Mobility, 36, 49-68. http://dx.doi.org/10.1016/j.rssm.2014.01.003

Solovieva, T.I., Denteea, E.D., Dowler, E.D., Walls R.T. (2011). Employer Benefits from Making Workplace Accommodations. Disability and Health Journal, 4, 39-45. http://dx.doi.org/10.1016/j.dhjo.2010.03.001

Thomas, H., Qiu, T. (2012). Work - Related Continuing Education and Training: Participation and Effectiveness. Journal of Workplace Lrearning, 24(3), 157-176. http://dx.doi.org/10.1108/13665621211209258

Tidwell, G.L., Rice D.S., Kropkowski, G. (2009). Employer and Employee Obligationds and Rights under the Uniformed Services Employment and Reemployment Rights Act. Business Horizons, 52, 243-250. http://dx.doi.org/10.1016/j.bushor.2009.01.003

Wallhaus, R.A. The Roles of Postsecondary Education in Workforce Development: Challenges for the State Policy. In Toward More Effective Learning Environments: the Roile of Postsecondary Education in Workforce Preparation, Racine, WI, February 22-24, 1996, $41 \mathrm{p}$.

Welters, R., Muysken, J. (2008). Inferring Employer Search Behaviour from Wage Subsidy Participation. Labour Economics, 15, 844-858. http://dx.doi.org/10.1016/j.labeco.2007.07.004

Workman, B., Armsby, P., Durrant, A., Frame, P. (2011). CETL for Work Based Learning: Enhancing Innovation and Creativity in Teaching and Learning. Higher Education, Skills and Work-Based Learning, 1(3), 273-288. http://dx.doi.org/10.1108/20423891111179669

Workman, B. (2007). Explorations by the Insider-Researcher Preparing for Work - Based Projects. Journal of Workplace Learning, 19(3), 146160. http://dx.doi.org/10.1108/13665620710735620

Biruta Sloka, Dr. oec., is a Professor with the University of Latvia. She has participated in several research projects, headed the Euro Faculty Riga Centre, been an advisor to six ministers of economy and an advisor of two ministers of education and science. She is a Member of Latvian Association of Econometrists, Member of Association of Professors of Higher Education of Latvia and the President of Latvian Association of Statisticians.

Address: Faculty of Economics and Management, University of Latvia, 5 Aspazijas Blvd., Riga LV-1050, Latvia

Phone: + 37129244966

E-mail: Biruta.Sloka@1u.lv

Ināra Kantāne received the Master degree in Social Science of Economics (Mg. oec.) in 2003 and the degree Dr. admin. in 2013. She is a Researcher with the University of Latvia and an Assistant Professor with the University College of Economics and Culture. Her field of study is small and medium business, factors influencing business development. She has been a lecturer and database-engineer with the Faculty of Economics and Management of University of Latvia, a lecturer with the University College of Economics and Culture a Researcher in ESF, ERAF projects and in the projects of University of Latvia. She is a Member of Latvian Association of Statisticians.

Address: Faculty of Economics and Management, University of Latvia, 5 Aspazijas Blvd., Riga LV-1050, Latvia

Phone: + 37129244966

E-mail: Inara.Kantane@lu.lv
Ilze Buligina received the MA degree (Cum Laude) from Maastricht

University, the Netherlands, in 2010. She has completed PhD studies at the University of Latvia. Her field of study is public administration. She is currently working at the Ministry of Education and Science, Latvia. She has coordinated and led several EU projects. Her research interests include public administration, responsible governance, labour force training to promote innovation. She has received the Top 3\% Student Award of Maastricht University in 2010.

Address: Faculty of Economics and Management, University of Latvia, 5 Aspazijas Blvd., Riga LV-1050, Latvia

Phone: + 37129478176

E-mail: ilze.buligina@gmail.com

Ginta Tora holds the degree of Master of Business Management. She is a Sector Leader of Academic Department, University of Latvia. Her field of study is higher and professional education quality assurance, efficient organization of studies.

Address: Faculty of Economics and Management, University of Latvia, 5 Aspazijas Blvd., Riga LV-1586, Latvia

Phone: + 37167034307

E-mail: Ginta.Tora@lu.lv

Juris Dzelme received the degree Dr. chem. in 1992, the title of Candidate of Science in Chemistry in 1979 and the qualification in Physics (Theoretical Physics) in 1969. His fields of study are education management and physics.

He is currently a Lead Researcher with the Institute of Chemical Physics of University of Latvia. He is Chairman of the Foundation "Higher Education Quality Evaluation Centre". His previous jobs were: Head of Higher Education Division of the Ministry of Education and Science; a Lecturer (part time) with the Faculty of Chemistry of the University of Latvia and with the Baltic International Academy; a Researcher and Coordinator in ESF, Erasmus, TEMPUS, Leonardo da Vinci projects and in the projects of the University of Latvia. His research interests include higher and professional education quality assurance, public administration and quantum chemistry.

$\mathrm{He}$ is an Ex-Member of the Board of Latvian Union of Scientists.

Phone: +37129283214

E-mail: Juris.Dzelme@lu.lv

Regina Buševica holds the degree of Master of Business Management. She is a Lecturer with the Faculty of Economics and Management, University of Latvia. Her field of study is office work and document management in modern environment, business informatics, office automation activities and potentialities of Finance accounting automation.

Address: Faculty of Economics and Management, University of Latvia, 5 Aspazijas Blvd., Riga LV-1050, Latvia

Phone: + 37129478176

E-mail: regina.busevica@lu.lv

Alise Buligina received the degree of Master of Philosophy from the University of Latvia. She is currently a Doctoral student with the University of Latvia. Her field of study is philosophical aspects of effective public administration organization.

Address: Faculty of Economics and Management, University of Latvia, 5 Aspazijas Blvd., Riga LV-1050, Latvia

Phone: + 37129478176

E-mail: Alise.Buligina@gmail.com

Pēteris Tora is a Student of Rotterdam University, the Netherlands. He has participated in several research projects related to the labour market and has several publications in this field.

E-mail: torapeteris@gmail.com 